\title{
Consumer perceptions of environmentally friendly products
}

\author{
M.T. Bendixen, M. Sandler \& D. Seligman \\ Graduate School of Business Administration, University of the Witwatersrand, P.O. Wits 2050, Republic of Sputh Africa
}

Received July 1993, accepted December 1993

\begin{abstract}
During the past decade, concern for the environment has emerged as a major socio-political issue among developed nations throughout the world and the increase in the number of environmentally friendly or 'green' products has been significant. The purpose of this exploratory study was to determine the types of products that are considered to be environmentally friendly as well as establishing consumer perceptions of these products. One of the main findings of the research was that 'green' products have achieved substantial awareness among consumers and they are not regarded as a gimmick or a fad. It was also established that the two main barriers that discouraged consumers from purchasing 'green' products were a perception that such products were not price competitive and scepticism regarding their supposed environmental benefits.
\end{abstract}

Gedurende die afgelope dekade het besorgdheid oor die omgewing as 'n emstige sosio-politiese saak onder ontwikkelde lande na vore getree en het dit 'n beduidende toename in die aantal omgewingsvriendelike of 'groen' produkte tot gevolg gehad. Die doel van hierdie verkenningsnavorsing was om vas te stel watter tipe produkte deur verbruikers as omgewingsvriendelik beskou word asook om die persepsie van verbruikers met betrekking tot hierdie produkte te bepaal. Een van die belangrikste bevindings van die navorsing was dat verbruikers baie bewus is van 'groen' produkte en dat hulle dit nie as ' $n$ gier beskou nie. Die navorsing het verder bewys die twee hoofredes wat verbruikers ontmoedig om 'groen' produkte te koop, is ' $n$ persepsie dat hierdie produkte nie prysmededingend is nie en dat daar twyfel bestaan ten opsigte van die veronderstelde omgewingsvoordele van dié produkte.

\section{Introduction}

During the past decade, concern for the environment has emerged as a major socio-political issue among developed nations throughout the world (Kirkpatrick, 1990). Given the many other social, political and economic problems faced by South Africa, it is not surprising that environmental issues are low on the list of policy issues of concern to business leaders in this country (Lee, Bendixen \& Sutherland, 1992). Nevertheless, in keeping with the trends in developed nations, the emergence of environmentally friendly or 'green' products has been significant. The number and range of green products offered to consumers by major retailers and leading brands is growing rapidly.

The purpose of this exploratory study was to examine:

- what types of products are considered environmentally friendly; and

- consumer perceptions of environmentally friendly products.

\section{Literature review}

The consumerism movement of the early 1960s forced marketers to begin considering the economic and social factors related to their products. Consumerism resulted in a change from the belief in the primacy of profit to a belief in the primacy of customer welfare. This paradigm shift resulted in marketers asking should a product be sold rather than could the product be sold (Abratt \& Sacks, 1988).

In an examination of social market research theory, Weiner \& Doescher (1991) identified four barriers that may cause consumers to refrain from acting in a pro-social manner:

- the desire to maintain one's freedom; people will generally oppose policies and actions that limit their freedom and choice of alternatives;

- the desire to avoid 'being a sucker'; this can result from performing a pro-social action which is ultimately seen as having no effect;
- self-interest; this often arises when there is a low benefitcost ratio associated with the pro-social action; and - mistrust; individuals may be unwilling to co-operate because they do not trust others to co-operate.

Weiner \& Doescher (1991) noted that whether or not these four barriers actually inhibit co-operation depends on whether the solution being proposed is structural or behavioural. A structural solution is a political act that restricts individual freedom while a behavioural solution is one in which consumers are asked to make voluntary sacrifices. The desire to maintain one's freedom is clearly a barrier to structural solutions. Avoidance of 'being a sucker', selfinterest and mistrust are barriers to behavioural solutions.

Prothero (1990) contended that, prior to the emergence of a large number of environmentally friendly consumers during the late 1980s, many companies only superficially subscribed to the concept of societal marketing. In many cases, societal marketing was generally applied to conform to specific environmental or health regulations or as a way of boosting the image of the company. Prothero (1990) dubbed this the 'top-down' approach. With the 'greening of consumers' and the rapid increase in environmental awareness among consumers, a 'bottom-up' approach has started to emerge. Here, the marketing department, after evaluating the demands of environmentally aware consumers, feeds the societal marketing concept up to management. This process has forced companies to adopt strategies that are more than simple window dressing. This conforms to Jay's (1990) contention that honesty can be highly profitable in green consumer marketing.

One of the main problems faced by companies marketing environmentally friendly products is that the purported 'greenness' of the product is always relative rather than absolute. Caimcross stated:

'Green consumers are, to the purer kind of environmentalist, the ultimate oxymoron. Consumers are the 
problem, not the solution: consuming uses up the earth's capacity to produce materials and absorb waste' (1990: 6).

However, he noted that:

'Consumers have done more to bring the environment to the attention of managing directors than any number of worthy commissions and earnest reports' (1990: 6).

The fact that the 'greenness' of a product is relative has resulted in some misleading marketing half-truths, trivial measures and marketing deceptions. Adams (1990) warned that the media are focussing their attention on exposing such hypocrisy. Davis (1991) believes that such actions could place the very promise of green marketing at risk and proposed that the development and marketing of truly green products should be part of a corporate plan. Such a plan would incorporate the following features:

- an explicit statement of corporate environmental orientation;

- environmental planning be an integral part of the longterm strategic planning process;

- an acknowledgement that total corporate image could be at stake; and

- profitability be maintained without environmental exploitation.

Ottman has identified the key myths that marketers have about green products:

'Myth 1:Green products cost more.

Myth 2: Green products don't perform as well as conventional products.

Myth 3: Green products appeal only to a small niche.

Myth 4: Green-inspired competitive advantages often are fleeting' (1993: 13).

In the face of the many pitfalls into which the marketer (or potential marketer) of green products could fall, it is

\section{Table 1 Legend of products}

\begin{tabular}{ll} 
No. & Product \\
\hline 1 & Cosmetics or make-up not tested on animals \\
2 & Orone-friendly sprays \\
3 & Magazines printed on recycled newspaper \\
4 & Glass containers and bottles \\
5 & Lead-free petrol \\
6 & Fruit and vegetables grown without insecticides \\
7 & Recyclable plastic packets \\
8 & Non-toxic paint and ink \\
9 & Products that have an 'environmentally friendly' label \\
10 & Electricity from Eskom \\
11 & Biodegradable washing-up liquid \\
12 & Products without preservatives \\
13 & Free-range eggs \\
14 & Photodegradable garbage bags \\
15 & Phosphate-free washing powder \\
16 & Mercury-free batteries \\
17 & Furniture made from wood of trees that can easily be regrown \\
18 & Concentrated fabric softener \\
19 & Re-usable plastic containers
\end{tabular}

important to examine consumer perceptions of green products. Thus the purpose of this research was to explore what types of products consumers perceive to be environmentally friendly as well as the perceptions of environmentally friendly products.

\section{Methodology}

The initial phase of the research comprised in-depth interviews with six experts, one from each of the areas of retailing, manufacturing, marketing, packaging, consumer affairs and environmentalism. The purpose of these interviews was to identify environmentally friendly products considered to be of importance. Nineteen products (see Table 1) were identified and incorporated into a questionnaire in which respondents were asked to rate their extent of agreement with the fact that these products were environmentally friendly using a five-point Likert scale. Respondents separately recorded that they might be unaware of the product or whether or not it was environmentally friendly.

Fifteen statements (see Table 2) reflecting the strategic or societal marketing issues relating to the marketing of environmentally friendly products were also incorporated into the questionnaire. Respondents were asked to rate their extent of agreement with these statements with respect to environmentally friendly products using a five-point Likert scale. Demographic details of the respondent as well as basic behaviours with respect to environmentally friendly products were also captured. The questionnaire was translated into Afrikaans and pretested among eight respondents of diverse cultural and educational backgrounds to check for comprehension of terminology. Only minor adjustments in phraseology were necessary for the finalization of the questionnaire.

Eight organizations (mainly large companies) based in Johannesburg that did not offer environmentally friendly

\section{Table 2 Legend of statements}

No. Statement
1 These products are a clever marketing gimmick.
2 They are too expensive when compared to other similar brands.
3 Buying 'green' will force companies to became more environmental-
ly aware.
4 They are of better quality than non-environmentally friendly
products.
5 They are worth spending money on to save the environment.
6 These products are inconvenient to use.
7 They are an investment for future generations.
8 They are less profitable for manufacturers and supermarkets.
9 These products help the country.
10 Buying these products is the fashionable thing to do.
11 These products are a fad that will die away.
12 Products claiming to be environmentally friendly should be tested
to see if this is tne; if they are, they should be given a special en-
14 Tironmentally friendly label by SABS.
13 They should be sold at a cheaper price to encourage people to buy
them.


products in their range were selected on a basis of convenience and willingness to participate in the study. A random sample of 15 to 25 employees was selected from the internal telephone directory of each organization. With the assistance of a contact person from the organization, this list was screened for illiterate employees before distributing the questionnaires for self-completion. This process yielded a total of 138 usable responses.

\section{Results}

Respondents were asked: 'How much have you heard about green products?'. The response profile is illustrated in Figure 1. The incidence of respondents having heard a fair amount or a lot about green products was measured at $81 \%$ which is relatively high.

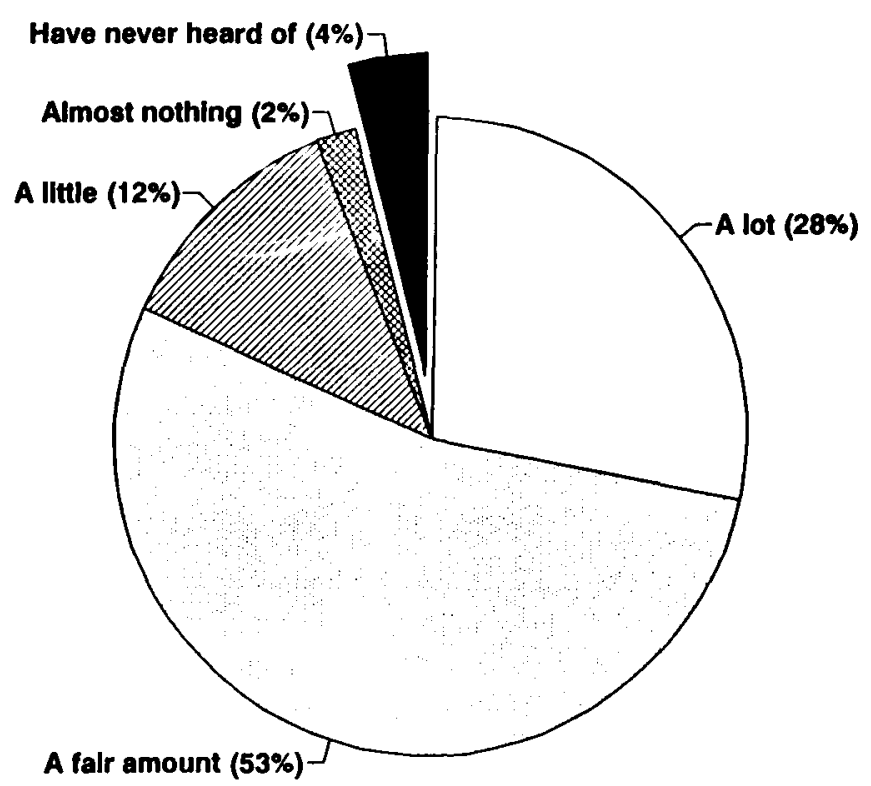

Figure 1 Awareness of green products

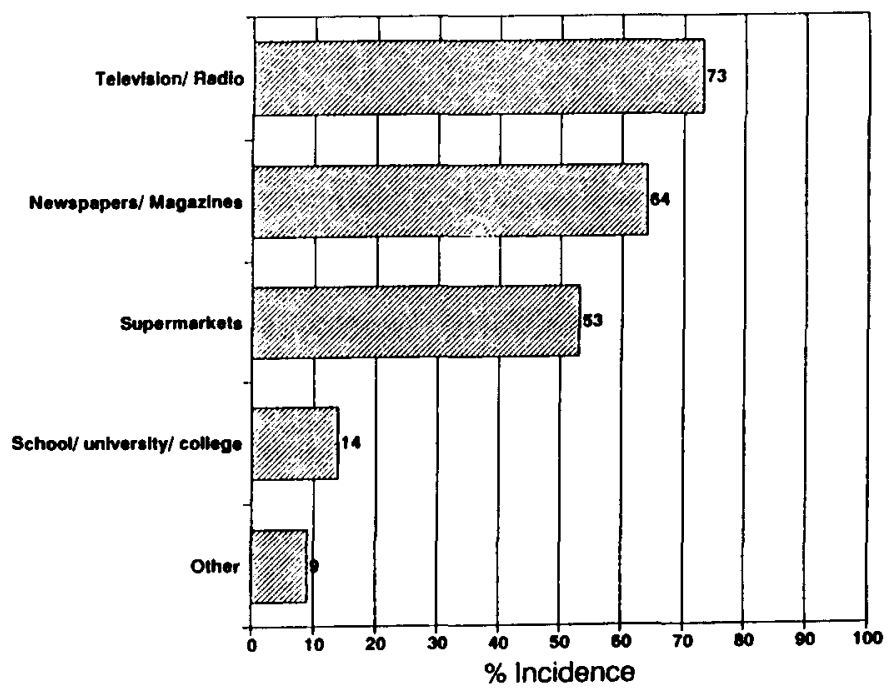

Figure 2 Source of information

Respondents were then asked: 'If you have heard about these products, where was this information from?'. The response profile is illustrated in Figure 2. It is apparent that both the electronic and written media have played a signi- ficant role in the communication process. The pro-active role of certain supermarket chains is also apparent.

As far as purchase behaviour is concerned, the response to the following question ' $\mathrm{D}$ o you, or the person doing the shopping in your household, give preference to green products above other products?' is illustrated in Figure 3 . While a degree of 'over-claiming' can be expected in the context of the research, there is little doubt as to the interest in green products among consumers.

The response profile to the question 'Would you be prepared to pay an extra $10 \%$ to buy environmentally friendly products in preference to other brands of similar quality?' is presented in Figure 4. Again, a degree of 'over-claiming' can be anticipated but there is a considerable willingness to pay a premium for selected green products.

The matrix of frequencies of response to the 19 products on the five-point Likert scale was subject to correspondence analysis. The Euclidian distance between scale points on the first two principal axes was used to create an interval scale ranging from 1 through to 5 . Details are presented in Table 3.

It is interesting to note that the interval scale is different from the usual allocation of numerical values of $1,2,3,4$ and 5 usually attributed to a Likent scale. The developed scale is characterized by the unusual proximity of Strongly Agree and Agree (4.507 to 5.000 rather than 4 to 5).

The rescaled mean ratings of the 19 produdts and the incidence of unawareness of the products are presented in Table 4.

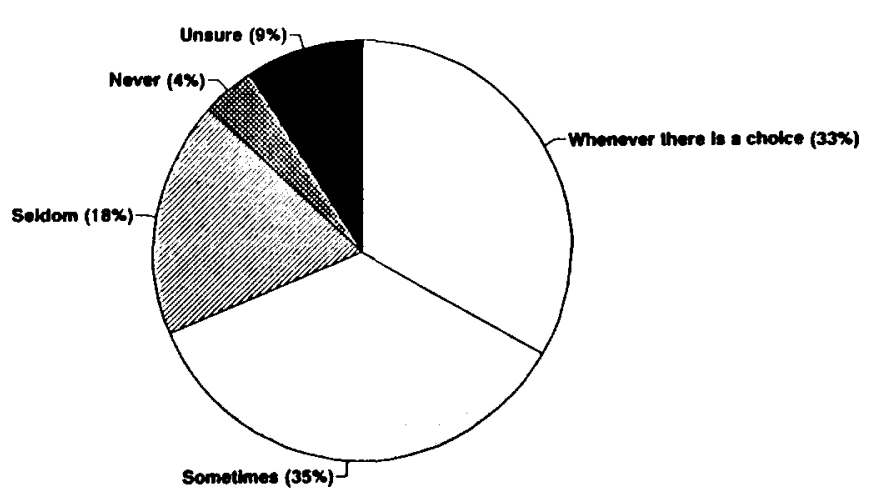

Figure 3 Preference for green products

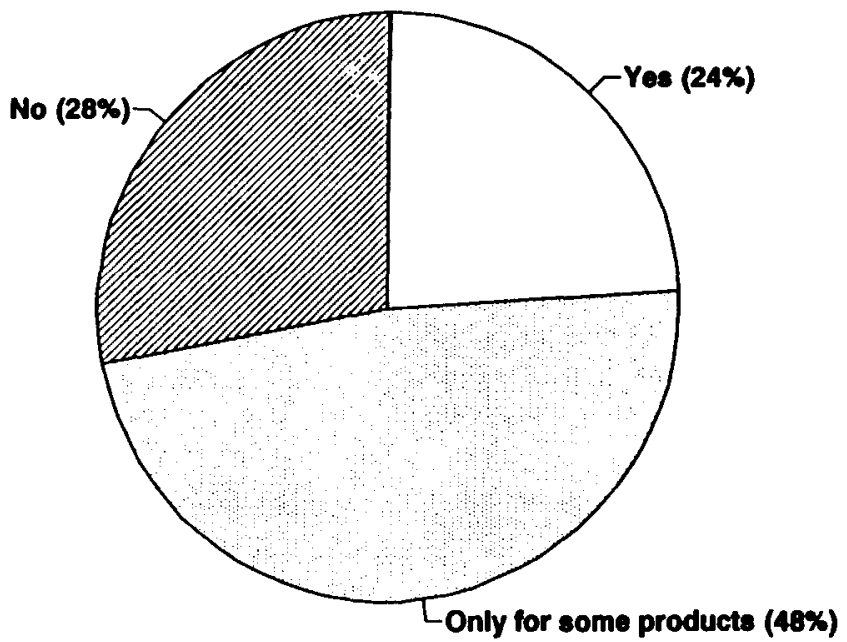

Figure 4 Willingness to pay a $10 \%$ premium for green products 
Table 3 Rescaling of five-point Likert scale to interval scale (products)

\begin{tabular}{lcccc}
\hline $\begin{array}{l}\text { Liken } \\
\text { Scale }\end{array}$ & $\begin{array}{c}\text { Ist Axis } \\
\text { co-ordinate }\end{array}$ & $\begin{array}{c}\text { 2nd Axis } \\
\text { co-ordinate }\end{array}$ & $\begin{array}{c}\text { Euclidean } \\
\text { distance to } \\
\text { next point }\end{array}$ & $\begin{array}{c}\text { Five-point } \\
\text { interval } \\
\text { scale }\end{array}$ \\
\hline Strongly dis- & & & & \\
agree & 0.278 & -0.406 & 0.341 & 1.000 \\
$\begin{array}{l}\text { Disagree } \\
\text { Neither agree }\end{array}$ & 0.443 & -0.107 & 0.407 & 1.998 \\
nor disagree & 0.207 & 0.225 & 0.453 & 3.185 \\
Agree & -0.197 & 0.019 & 0.169 & 4.507 \\
Strongly agree & -0.338 & -0.074 & - & -5.000 \\
\hline
\end{tabular}

Table 4 Mean rating of products

\begin{tabular}{lrl}
\hline $\begin{array}{l}\text { Mean } \\
\text { rating }\end{array}$ & $\begin{array}{l}\text { Unawareness } \\
\text { incidence (\%) }\end{array}$ \\
\hline 4.08 & 8 & Product \\
4.08 & 3 & Oronazines printed on recycled paper \\
4.02 & 4 & Fruit and vegetables grown without insecticide \\
3.94 & 15 & Biodegradable washing-up liquid \\
3.82 & 7 & Recyclable plastic packets \\
3.79 & 10 & Non-toxic paint and ink \\
3.79 & 7 & Products that have an 'environmentally friend- \\
& & ly' label \\
3.78 & 24 & Mercury-free batteries \\
3.78 & 7 & Fumiture made from wood of trees that can \\
& & easily be regrown \\
3.71 & 17 & Photodegradable garbage bags \\
3.68 & 17 & Free-range eggs \\
3.60 & 23 & Phosphate-free washing powder \\
3.60 & 9 & Products without preservatives \\
3.47 & 10 & Lead-free petrol \\
3.37 & 6 & Re-usable plastic containers \\
3.29 & 5 & Glass containers and botles \\
3.24 & 14 & Cosmetics or make-up not tested on animals \\
3.16 & 22 & Electricity from Eskom \\
2.75 & 14 & Concentrated fabric softener \\
\hline & &
\end{tabular}

From the results presented in Table 4, it is apparent that some doubt exists in consumers' minds as to whether electricity or concentrated fabric softener are really environmentally friendly products. Magazines printed on recycled paper, ozone friendly sprays, fruit and vegetables grown without insecticides and biodegradable washing-up liquid were perceived the most strongly to be environmentally friendly products.

The incidence of unawareness or lack of certainty as to whether mercury-free batteries, phosphate-free washing powder and electricity represented environmentally friendly products were all measured in excess of $20 \%$. This high incidence may be attributed to the fact that the technical aspects of environmental impact for these products is not commonly known or has not been appropriately communicated to consumers. This is in sharp contrast to products such as ozone friendly sprays and fruit and vegetables grown without insecticides.
Table 5 Rescaling of five-point Likert scale to interval scale (statements)

\begin{tabular}{lcccc}
\hline $\begin{array}{l}\text { Likent } \\
\text { Scale }\end{array}$ & $\begin{array}{c}\text { 1st Axis } \\
\text { co-ordinate }\end{array}$ & $\begin{array}{c}\text { 2nd axis } \\
\text { co-ordinate }\end{array}$ & $\begin{array}{c}\text { distance to } \\
\text { next point }\end{array}$ & $\begin{array}{c}\text { Five-point } \\
\text { interval } \\
\text { scale }\end{array}$ \\
\hline $\begin{array}{l}\text { Strongly } \\
\text { disagree }\end{array}$ & 0.706 & -0.374 & 0.310 & 1.000 \\
$\begin{array}{l}\text { Disagree } \\
\text { Neither agree }\end{array}$ & 0.601 & -0.082 & 0.384 & 1.558 \\
nor disagree & 0.294 & 0.148 & 0.671 & 2.249 \\
Agree & -0.359 & 0.304 & 0.858 & 3.456 \\
Strongly agree & -0.969 & -0.299 & - & 5.000 \\
\hline
\end{tabular}

The matrix of frequencies of response to the 15 statements on the five-point Likert scale was also subjected to correspondence analysis and an interval scale developed in the same way as previously described. Details are presented in Table 5.

Again it may be observed that the interval scale is quite different from the usual allocation of numerical values of 1 , 2, 3, 4 and 5 usually attributed to a Likert scale. The developed scale is characterized by the unusual proximity of Strongly Disagree and Disagree (1.000 to 1.558 rather than 1 to 2) as well as the unusually large distance between Strongly Agree and Agree (3.456 to 5.000 rather than 4 to 5).

The data scaled in this way was subject to principal component factor analysis. A five-factor solution was chosen as all these factors had eigen values in excess of unity and the fact that the factors were readily interpretable. The rotated factor loadings (varimax) are presented in Table 6.

\section{Factor 1: Green products are a fad}

Statements $1,10,11 \& 15$ load onto the first factor. All of these statements point to green products being a fad, i.e. they are a marketing gimmick of little real value.

\section{Table 6 Rotated factor loadings}

\begin{tabular}{ccccccc}
\hline State- & & & & & & Commu- \\
ment & Factor 1 & Factor 2 & Factor 3 & Factor 4 & Factor 5 & nality \\
\hline 1 & +0.7350 & -0.0915 & +0.0770 & +0.1708 & +0.0457 & 0.5859 \\
2 & +0.2735 & -0.1505 & -0.0598 & +0.6399 & -0.1378 & 0.5295 \\
3 & -0.0357 & -0.7076 & +0.2489 & +0.0444 & +0.0997 & 0.5759 \\
4 & -0.3994 & +0.1917 & -0.5377 & -0.0546 & -0.0064 & 0.4884 \\
5 & 0.1219 & +0.7583 & -0.1150 & -0.0615 & -0.3233 & 0.7114 \\
6 & +0.4081 & -0.2798 & +0.6398 & +0.1174 & +0.0439 & 0.6699 \\
7 & -0.0257 & +0.8229 & -0.0534 & +0.0684 & -0.1225 & 0.7003 \\
8 & +0.0429 & -0.0029 & +0.0258 & +0.0225 & +0.8744 & 0.7676 \\
9 & -0.2451 & +0.6875 & +0.1949 & +0.0128 & +0.3249 & 0.6765 \\
10 & +0.7076 & -0.0743 & +0.0288 & +0.2361 & -0.1214 & 0.5775 \\
11 & +0.7487 & +0.0001 & -0.1573 & -0.1272 & +0.1388 & 0.6207 \\
12 & -0.0688 & +0.2242 & -0.2668 & +0.6916 & -0.0576 & 0.6078 \\
13 & +0.0855 & +0.0250 & +0.1373 & +0.6973 & +0.2240 & 0.5632 \\
14 & -0.0213 & +0.2009 & +0.8018 & -0.1501 & +0.0752 & 0.7119 \\
15 & +0.5240 & -0.2831 & +0.1308 & +0.0183 & +0.4629 & 0.5864 \\
\hline & & & & & & \\
\hline
\end{tabular}




\section{Factor 2: Green products for a better future}

Statements 3, 5, 7 \& 9 load onto the second factor. All of these statements have an underlying theme of the long-term benefits of green products.

\section{Factor 3: Green products require extra effort}

Statements 4, 6 \& 14 load onto the third factor. The underlying theme is far from obvious but seems to relate to the perception that extra effort is required to both buy and use green products.

\section{Factor 4: Green products should represent value for} money

Statements $2,12 \& 13$ load onto the fourth factor. The theme clearly deals with affordable pricing and verified claims. This is a classical interpretation of value for money.

Factor 5: Green products are a waste of time for everybody

Statements $8 \& 15$ load onto the fifth factor. These represent the cynical feeling that these products are not of any real benefit to the retailer, the manufacturer or the environment.

Factor scores were calculated as the mean of the statements loading onto that factor. These scores were subject to a k-means cluster analysis. A six-cluster solution yielded a $50.49 \%$ reduction in variance and displayed an elbow in the scree plot of variance reduction. The mean factor scores for the resulting six clusters is presented in Table 7.

\section{Cluster 1: Green populists}

The first cluster, representing $12 \%$ of respondents, is characterized by above average agreement with factors $2 \&$ 4 and below average agreement with factor 1 . These respondents see green products as offering a belter future and not being a fad provided that they represent value for money.

\section{Cluster 2: Unconvinced non-greens}

The second cluster, representing $22 \%$ of respondents, is characterized by below average agreement with factors 2 \& 4. It is apparent that these respondents are uninterested in the concept of green products.

\section{Cluster 3: Green cynics}

The third cluster, representing $8 \%$ of respondents, is characterized by above average agreement with factors 1 \&

Table 7 Factor score means by cluster

\begin{tabular}{llllll}
\hline & Factor 1 & Factor 2 & Factor 3 & Factor 4 & Factor 5 \\
\hline Cluster 1 & 1.54 & 4.55 & 1.86 & 4.25 & 1.61 \\
Cluster 2 & 2.25 & 2.66 & 1.99 & 2.94 & 2.34 \\
Cluster 3 & 3.75 & 3.42 & 1.76 & 4.09 & 3.01 \\
Cluster 4 & 1.78 & 4.27 & 2.37 & 2.99 & 1.55 \\
Cluster 5 & 2.16 & 2.94 & 1.88 & 4.20 & 1.91 \\
Cluster 6 & 2.65 & 3.50 & 3.45 & 3.56 & 3.67 \\
Total & 2.19 & 3.45 & 2.12 & 3.60 & 2.12 \\
\hline
\end{tabular}

5. As such, they see green products as a fad and a waste of time for everybody.

\section{Cluster 4: Green elitists}

The fourth cluster, representing $22 \%$ of respondents, is characterized by above average agreement with factor 2 and below average agreement with factor 4 . As such they see the benefits of a better future resulting from the use of green products and are probably prepared to pay more for green products.

\section{Cluster 5: Price conscious could-be greens}

The fifth cluster, representing $28 \%$ of respondents, are characterized by above average agreement with factor 4 . As such, they are sensitive to the value for money that green products represent and, as a consequence, are probably only light users of such products.

\section{Cluster 6: Hassled non-greens}

The sixth cluster, representing $8 \%$ of respondents, are characterized by above average agreement with factors 3 \& 5. As such, they find that green products represent an extra effort and are a waste of time for everybody.

The relative size of these clusters or market segments is illustrated in Figure 5.

\section{Conclusions}

It is apparent from this research that environmentally friendly or green products have achieved a substantial awareness among consumers. Green products are not a gimmick or a fad and represent an economic vote for a better environment in the future.

While many consumers are prepared to pay a premium for certain green products, many more would use green products if they were perceived as representing value for money. This is a key factor in the successful marketing of green products.

Another key issue in the successful marketing of green products is the substantiation of any environmental claims. A recognized verification mark by an independent and credible body would assist in this process.

In many instances, the environmentally damaging aspect of a product is technical in nature (e.g. mercury in batteries or phosphates in washing powders). Consumers need to be educated in the hazards of using such products and the benefits of using their green equivalents. Thus, communication is another key factor to the marketing of green products.

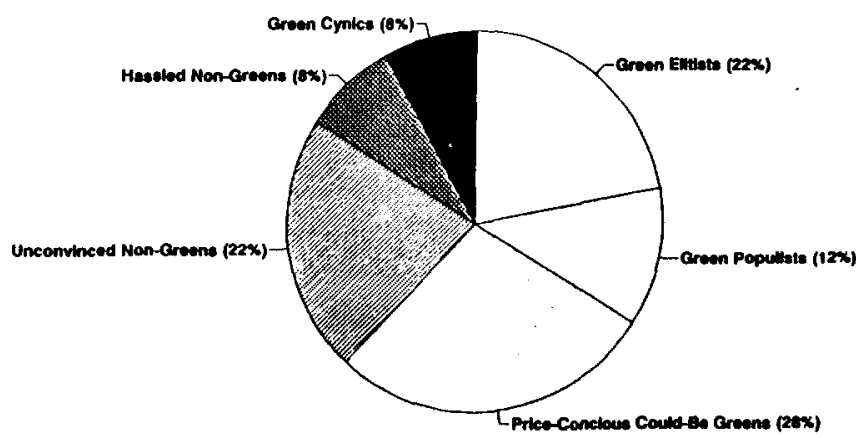

Figure 5 Green market segments 
The 'green elitists' and 'green populists' represent $34 \%$ of the respondents in this research indicating an already sizeable market for green products. The 'price-conscious couldbe greens' and 'unconvinced non-greens' represent a further $50 \%$ of respondents. These segments are the potential greens of the future provided that they can be persuaded by appropriate pricing and communication strategies. The 'green cynics' and 'hassled non-greens' represented $16 \%$ of respondents and are unlikely to use green products to any significant extent in the short or medium term.

The findings of this exploratory study are aligned with those of Weiner \& Doescher (1991), Prothero (1990), Davis (1991) and Ottman (1993) and provide contextual relevance in the South African market. It is important to track these consumer perceptions with time as green products are at the early stages of their product life cycles and subject to environmental 'happenings' (e.g. a hazardous waste spillage, a new scientific discovery). Future research should also focus on the nature and importance of a 'green' corporate image to a business. The credibility and success of a green product range or brand is likely to be critically dependent on the environmental track record of the business.

\section{References}

Abrath, R. \& Sacks, D. 1988. 'The marketing challenge - towards being profitable and socially responsible', Jownal of Business Ethics, July, pp.497-507.

Adams, R. 1990. 'The greening of consumerism', Accountancy, June, pp.80-83.

Caimcross, F. 1990. 'The environment: an enemy and yet a friend', The Economist, September.

Davis, J.J. 1991. 'A blueprint for green marketing', Journal of Business Strategy, July/August, pp.14-17.

Jay, L. 1990. 'Green about the tills: markets discover the ecoconsumer', Management Review, June, pp.24-29.

Kirkpatrick, D. 1990 . 'Environmentalism - the new crusade', Forture, Febnary 12, pp.24-30.

Lee, R.H., Bendixen, M.T. \& Sutherland, M.M. 1992. 'The private sector's involvement in public policy: issues and strategies', S.A.J. Bus. Manage., Vol. 23, No. 3/4: 642-669.

Ouman, J. 1993. 'Edison winners produce responsible products that consumers will buy', Marketing News, Vol. 27, No. 10 . $13 \& 18$.

Prothero, A. 1990. 'Green consumerism and the societal marketing concept: marketing strategies for the 1990's', Journal of Marketing Managemen, Vol. 6, No. 2: 87-103.

Weiner, J.L. \& Doescher, T.A. 1991. 'A framework for promoting cooperation', Journal of Marketing, April, pp.38-47. 